UNRAM Law Review is licensed under a Creative Commons Attribution 4.0 International License, which permits unrestricted use, distribution, and reproduction in any medium, provided the original work is properly cited. p-ISSN: 2548-9267 | e-ISSN : 2549-2365, Open Access at : http://unramlawreview.unram.ac.id/index.php/ulr

\begin{tabular}{c|c|c|c|c|}
\hline Volume & Issue & Page & October & p-ISSN: 2548-9267 \\
\hline 4 & 2 & $163-173$ & 2020 & e-ISSN : 2549-2365
\end{tabular}

\title{
The Application of the Best Interest of the Child Principle as a Basis for Determining Child Custody
}

\author{
Angela Melani Widjaja \\ Faculty of Law, Universitas Airlangga \\ Jl. Dharmawangsa Dalam Selatan, Airlangga, Kec. Gubeng,Kota SBY, Jawa Timur \\ E-mail: angelamelani97@gmail.com \\ Ike Yeni Kartika Sari \\ Faculty of Law, Universitas Airlangga \\ Jl. Dharmawangsa Dalam Selatan, Airlangga, Kec. Gubeng,Kota SBY, Jawa Timur \\ E-mail:ikeyeni27@gmail.com \\ Hasna Firas Isza Fadhilah \\ Faculty of Law, Universitas Airlangga \\ Jl. Dharmawangsa Dalam Selatan, Airlangga, Kec. Gubeng,Kota SBY, Jawa Timur \\ E-mail: fadhilahhasna@yahoo.com \\ Devi Sukma Ayuningtyas \\ Faculty of Law, Universitas Airlangga \\ Jl. Dharmawangsa Dalam Selatan, Airlangga, Kec. Gubeng,Kota SBY, Jawa Timur \\ E-mail: devi.sukma.ayuningtyas-2019@fh.unair.ac.id
}

\begin{abstract}
This research was conducted to introduce the principle of the best interest of the child as a basis for judges to create decisions regarding the child custody that reflects child protection. Based on this idea, the problem formulations in this research are: First of al, what is the basis for determining child custody by judges in Indonesia? and Secondly, what is the basis for determining child custody that reflects the principle of The Best Interest of The Child This paper is legal research which applies statute approach, conceptual approach, and case approach. Based on this research, it was found that Firstof all, there are differences for judges in determining child custody in Indonesia for Muslim and non-Muslim couples. For Muslim couples, if the child is 12 (twelve) years old and over, the custody of the child is prioritized to be handed to the mother and if the child is under 12 (twelve) years of age, then custody will be given to the mother. For non-Muslim couples, generally, the custody of the child will be prioritized to be given to the mother. Secondly, The basis for determining the provision of child custody that reflects the principle of the best interest of the child for Muslim couples is that if the child is over 12 (twelve) years old, therefore the judge should not necessarily prioritize giving custody to the mother, rather they must pay attention to aspects of the need and the wishes of the child. If the child is not yet 12 (twelve) years old, the judge should also consider the desires and needs of the child and not necessarily give custody to the mother. The basis for determining the granting of child custody that reflects the principle of the best interest of the child for non-Muslim couples is when the judge does not necessarily give priority to the mother, but should consider the desiresand needs of the child.
\end{abstract}

Keywords: Custody of children; Divorce; The Best Interest of The Child Principle. 


\section{INTRODUCTION}

In Article 1 of Law Number 1 of 1974 concerning Marriage (hereinafter referred to as Law 1/1974), the definition of marriage is defined as: "the bond between a man and a woman as husband and wife to form a happy and eternal family (household) based on the God's will. " If we take a look at the Compilation of Islamic Law (hereinafter referred to as KHI/CIL) which incidentally is one of the guidelines for the rules for Moslems, as it can be seen that marriage is also defined in a similar way, namely: "Marriage according to Islamic law is the most strong contract or mitssaqanghalidzan to obey Allah>s orders and to conduct one is a form of worship.» If we draw a synthesis of these two definitions, we can conclude from the phrase «eternal» in the definition in Law 1/1974 and the phrase «the most strong contract" in KHI/CIL, it can be interpreted that marriage is a bond that ideally very strong and cannot be separated. The strength of this marriage bond is actually in accordance with Zulfaini's opinion, that "... a marriage is conductedthus one day it can be built eternally based on the Supreme Lordship until death separates the two ..."

If we look at the two definitions of marriage in Law 1/1974 and KHI/CIL, it can be interpreted that ideally, marriage is an eternal bond, but in reality, it is common for these marriages to end halfway or known as divorce. This is also understood by legislators, therefore legislators provide limitations on the reasons for divorce which is a manifestation of the principle of "making divorce hard and difficult" which is a logical consequence for the concept of an ideal marriage bond which is an eternal bond.

Several reasons for divorce that are recognized by statutory regulations include, for example, adultery, the abandonment of one of the parties for 2 (two) consecutive years without the permission of the other party and valid reasons, one of the parties gets imprisonment of 5 (five) ) years or a heavier sentence after the marriage takes place, etc., One party commits abuse or serious mistreatment to the other party, and so on.

For Muslim couples, there are 2 (two) additional reasons, namely husbands violating the taklik-talak and religious conversion ormurtadwhich causes dissonance in the household. From the perspective of the concept of marriage, which is an engagement between 2 (two) people (a woman and a man), it is as if when the agreement is broken, the impact will only be on the involved parties. However, it turns out that there are parties outside the 2 (two) people who are potentially affected by the divorce. One of the parties potentially affected by the divorce is the child born in the marital relationship between the woman and the man.

In Article 7 paragraph (1) of Law Number 35 of 2014 concerning Amendments to Law Number 23 of 2002 regarding Child Protection (hereinafter referred to as Law 35/2014), it is stipulated that children have the right to be cared for by their parents. If we refer to Article 26 paragraph (1) of Law 35/2014, it is stated that parents are responsible for the care of their children. The ideal parental context referred to in Law 35/2014 is father and mother. Thus, it can be interpreted that the substantive rights of the child to be cared for are derived from the child's parents (father and mother).

The rights of the child to substantive care that should have been obtained from both parents must be derogated by the divorce of the parents which causes the child to be unable to substantially enjoy their rights. With a divorce, there will automatically be a determination of who legally responsiblefor the child. There are 
even times when the right to care their children is fought over by the parent. Men and women who are the father and mother of the child sometimes feel more entitled and worthy to care for the child.

In the context of competing for custody of children, it is generally included inposita and petitum, both in a lawsuit and a lawsuit on reconciliation related to the divorce. In this case, the one who will decide on the party entitled to care for the child is the judge. The judge will consider the party entitled to care for the child. Related to the consideration in determining who has the right to determine custody of children, this brings us to the legal problems that came along with it. On the one hand, there are times when the judge considers the wishes of the child, so the judge calls the child in the trial to be asked which is related to the child's preference, but on the other hand, the judge considers the child's needs, so the judge considers from the side of the parent and which parents have better abilities to raise the child. The dualism of the judge in considering the custody of the child, not to mention the perspective of the parents who want to take care of the child. These things lead to complex legal problems for judges to determine custody of the child.

With so many things that can be used as a consideration in determining custody of a child, the judge also can use the principle of the best interest of the child which is a principle in the Convention on The Rights of The Child (hereinafter referred to as CRC) which has been ratified by Indonesia based on Presidential Decree Number 36 of 1990 concerning Ratification of the Convention on The Rights of The Child (hereinafter referred to as Kepres / Presidential Decree No. 36/1990). The principle of the best interest of the child is simply a principle that uses consideration, that the best interest of the child is the main thing that must be considered. On this basis, this principle can be used by judges as a guide in deciding to whom the custody of the child should be granted.

Based on this background, the problem formulations in this article are, first of all, what is the basis for determining custody of children by judges in Indonesia? And secondly, what kind of basis for determining child custody, which reflects the principle of The Best Interest of The Child? This research was conducted for some purposes. First of all, to understand the basis for judges to determine custody of children in Indonesia. And finally, to understand the basis for judges to determine custody of children that reflects the principle of the best interest of the child

The novelty of this article compared to previous similar articles are:

1. Article by Ahmad ZaenalFanan titled: "Disputes on Child Custody in Family Law with a Gender Justice Perspective". The articlediscusses issues related to child custody, but what is used as a tool for analysis is the theory of gender justice, while instead in this article the principle of the best interest if the child is used;

2. Article by Evans AngokamingDjehadut and Ni PutuPurwanti entitled: "The Application of" The Best Interest of The Child "Principle in the Life of Children Who Are Forced to Work in Indonesia". In this articlediscusses the principle of the best interest. 


\section{ANALYSIS AND DISCUSSION}

\section{The Ratio Decidendi for Judges in Determining Child Custody Rights in Indonesia}

If you look at the grouping based on the legal system, it can be seen that Indonesia is a country that is classified as a country that adheres to the continental European system (civil law system). In a country that adopts the Continental European system, the main source of law is legislation. This has a juridical consequence, that if there are legal problems, the first thing to look at is the provisions in the legislation. Thus, the judge has to look for provisions in statutory regulations related to the legal problems. This is following Henry Merryman's opinion, which stated: "The judge becomes a kind of expert clerk. He is presented with a fact situation to which a ready legislative response will be readily found in all except the extraordinary case. His function merely to find the right legislative provision, couple it with the fact situation, and bless the solution that is more or less automatically produced from the union (emphasis on the sentence given by the author)." The classification of Indonesia as a civil law system country is related to the determination of child custody rights with juridical consequences, that in determining child custody, the first thing the judge must consider is the provisions in the legislation. Before understanding the relation to the determination of child custody in statutory regulations, it must first be understood that there are classifications related to Muslim and nonMuslim couples. For non-moslem couples, they generally comply with Law 1/1974, while for Muslim couples the KHI/CIL also applies lexspecialis.

Figure 1. Couple Classifications.

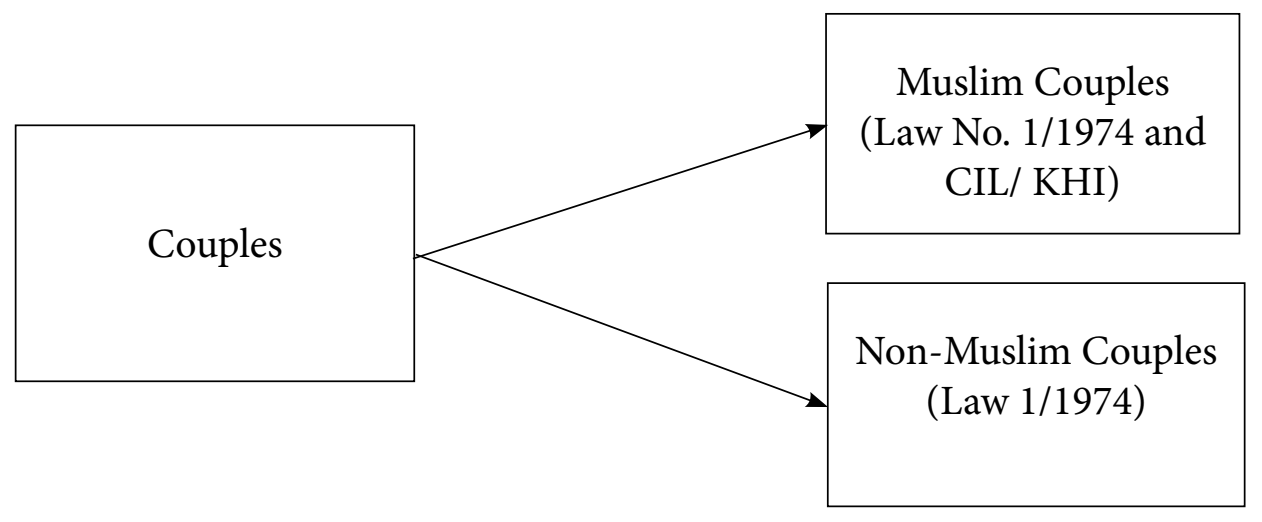

Regarding the determination of child custody for Muslim couples, there are actuallymore classifications, namely:

1. For children aged 12 (twelve) years and over

For children age 12 (twelve) years and over, there are no provisions which in an experisverbisway regulate the parties who have the right to care for the child in the event of a divorce. In this case, the judge will generally grant custody of the child to the mother. This conclusion is based on the consideration that children generally need the role of the biological mother more in their growth. Cum adsunttestimoniarerum, quid opus estverbist, is a legal postulate that has a depth of meaning, that when there is real evidence, there is no need for further explanation. ${ }^{1}$

\footnotetext{
${ }^{1}$ Peter Jeremiah Setiawan, Xavier Nugraha, Michael Enrick. (2020). "Analisis Kedudukan Keterangan Korban Terkait Kejahatan Terhadap Harta Kekayaan Dalam Lingkungan Keluarga: Sebuah Antinomi Antara Hukum Materil Dengan Formil”. Al-Daulah: Jurnal Hukum Pidana dan Ketatanegaraan, 9(1): 99-118.
} 
Regarding mothers who are usually given custody of children, it can be seen for example in Decree Number 219/Pdt.G/2011/PA.TA. In this decree, the judge gave custody of the Plaintiff, who in that case was the mother of the child, even though the child's father was also capable. This shows the tendentiousness of judges who prioritize mothers over fathers even though they are both capable. This decision was later strengthened in Decree 311/ Pdt.G /PTA.Sby.

2. For children under 12 (twelve) years of age

For children aged 12 years and under, there is an arrangement in an experisverbis way which determines custody of the child. This is contained in Article 105 letter .a of KHI/CIL which regulates that: " $a$. The care of children who are not yet considered as mumayyiz or not yet 12 years old is the right of the mother (emphasis on the sentence given by the author). "This shows that children who are not yet 12 years old automatically become custody of the mother. Regarding this matter, it can be seen in decision number 74 / Pdt.G / 2014 / PA.Dps. In the ratio decendi, the judge stated that:" Considering that the plaintiff desire, the Panel of Judges to determine that the children of the plaintiff and defendant are in the care of the plaintiff, the plaintiff's claim is to be considered as it is per Article 105 of the Compilation of Islamic Law." On this basis, in his verdict, the judge handed determines: ${ }^{3 \text { "D }}$ etermining the child named XXXX, Female, born on November 25, 2012 to be under the care/hadhanah of the plaintiff (mother) because the child is not yet considered to be mumayyiz or is still under 12 years old."

When there is still an experisverbis arrangement regarding the party who has the right to care for the child in the event that the child is under 12 years of age for moslem couples, this is different for non-Moslem couples. For non-Moslem couples, there are no regulations at all regarding who has the right to care for children. If in a legislation a void is found, the legal solution is to look at other sources of law. In general, there are 6 (six) sources of formal law, namely: 4

1. Laws and Regulations;

2. Customs;

3. Agreement;

4. Treaty;

5. Jurisprudence; and

6. Doctrine.

Regarding the determination of child custody for non-Moslem couples, it is not regulated in the laws and regulations, but there is another source of law related the issue, namely jurisprudence. The jurisprudence related to the determination of child custody for non-Muslim couples, namely:

1. The decision of the Supreme Court No. 126 K / Pdt / 2001 dated 28 August 2003 stated that: "In the event of a divorce, the child who is still underage should be left to the closest and familiar person to the child, namely the mother (emphasis on the sentence given by the author).»

\footnotetext{
${ }^{2}$ Denpasar District Court Verdict Number 74/Pdt.G/2014/PA.Dps, p.15.

${ }^{3}$ Ibid, p.16.

${ }^{4}$ Enju Juanda. (2017). "Penalaran Hukum (Legal Reasoning)”. GaluhJustisi, 5(1): 157-167.
} 
2. The decision of the Supreme Court No. 102 K / Sip / 1973 dated 24 April 1975, stated: "Basedonthejurisprudenceregarding childguardianship, whichstatedis that thebiological mother is prioritized, especially for children who are still young, because the child's interests are the criterion unless it is proven that the mother is unable to take care of the child (thickening of the author). "

Based on these 2 (two) jurisprudences, it can be understood that regarding to the handover of child custody to a divorced non-Moslem couple, the biological mother of the child will be prioritized. In this case it is a little different from Muslim couples, which in fact there is a differentiation of classifications as for children under 12 (twelve) years old their custody will definitely be granted to their mother, while those over 12 (twelve) years of age are prioritized to be given to their mother. The following is a table to differentiate between the determination of child custody by judges for Muslim and non-Muslim couples:

Table 1. Differentiation between the determination of child custody by judges for Muslim and non-Muslim

\begin{tabular}{|c|c|c|c|}
\hline No & Differences & Muslim Couples & $\begin{array}{r}\text { Non-Muslim } \\
\text { Couples }\end{array}$ \\
\hline 1 & $\begin{array}{l}\text { Legal Basis in } \\
\text { the Legislation }\end{array}$ & $\begin{array}{c}\text { Article no. } 105 \text { letter a in } \\
\text { Compilation of Islamic Law }\end{array}$ & $\begin{array}{r}\text { There are no rules that } \\
\text { determine who has the } \\
\text { right to care for chil- } \\
\text { dren. }\end{array}$ \\
\hline 2 & Differentiation & $\begin{array}{r}\text { There are two differentiations, } \\
\text { namely:1. Children aged } 12 \\
\text { (twelve) years and over; } \\
\text { Children under } 12 \text { (twelve) } \\
\text { years old. }\end{array}$ & $\begin{array}{r}\text { There is no differentia- } \\
\text { tion. }\end{array}$ \\
\hline 3 & Custody & $\begin{array}{r}\text { For children } 12 \text { (twelve) } \\
\text { years old and over, custody } \\
\text { rights are given priority to the } \\
\text { mother; For children under } 12 \\
\text { (twelve) years old, absolute } \\
\text { custody will be given to the } \\
\text { mother. }\end{array}$ & $\begin{array}{r}\text { Custody rights are } \\
\text { given } \\
\text { priority to the mother }\end{array}$ \\
\hline
\end{tabular}

\section{Determination of Child Custody that Reflects the Principles of the Best Interest of the Child in Indonesia}

Ex verroverrononnisiverum. A classic legal adage that has a deep meaning, that understanding the correct concept will result in the correct conclusion ${ }^{5} \mathrm{With}$ that in mind, to understand the determination of child custody that reflects the principle of the best interest of the child, it is necessary to first understand the principle of the best interest of the child itself. Related to the principle of the best interest of the child, it can be found in Article 3 of the CRC which states that:

\footnotetext{
${ }^{5}$ Muhammad Yassin. (2016). "Perlindungan Hukum Bagi Warga Negara Dalam Pelaksanaan Mutasi Pegawai Negeri Sipil”. Yuridika, 31(2): 254-272.
} 
1. In all actions concerning children, whether undertaken by public or private social welfare institutions, courts oflaw, administrativeauthorities or legislative bodies, the bestinterests of the child shall be a primary consideration.

2. States Parties undertake to ensure the child such protection and care as is necessary for his or her well-being, taking into account the rights and duties of his or her parents, legal guardians, or other individuals legally responsible for him or her, and, to this end, shall take all appropriate legislative and administrative measures.

3. States Parties shall ensure that the institutions, services and facilities responsible for the care or protection of children shall conform with the standards established by competent authorities, particularly in the areas of safety, health, in the number and suitability of their staff, as well as competent supervision (thickening of the author).

It can be seen clearly in the CRC that has been ratified by Indonesia, that the best interests of the children must be the main consideration in the country's legal politics. ${ }^{6}$

The CRC also instructs the state to guarantee the child's rights through legislative, administrative and, judicial means Thus, in Indonesia, which in fact has ratified the CRC through Presidential Decree 36/1990, should also implement the principle of the best interest of the child in all aspects, including the judicial aspect. This means that in terms of determining custody by judges, which incidentally is a judicial domain, should also consider the best interests of the child.

Regarding the judge who should also consider the principle of the best interests of the child in determining the provision of custody, it can also be seen implicitly in Law 35/2014. In the general explanation of Law 35/2014, it is stated that child protection must be considered heavily, one of which, on the principle of the best interests of the child. Furthermore, in Article 14 paragraph (1) of Law 35/2014, it states that: "Every child has the right to be cared for by his own parents unless there is a valid reason and/or legal rule indicating that the separation is in the best interest of the child and is the last consideration." On the basis of Article 14 paragraph (1) of Law 35/2014, it can be seen that children should have the right to be fully cared for by their parents, but when there is separation, the judge must determine on the basis of the best interests of the child.

Regarding the realization of the principle of best interest in determining the provision of child custody, there should be 2 (two) aspects that should be considered, namely:

1. The Child's Needs

In relation to the needs of thechildren, it is actually related to survival rights, which is one of the 4 (four) main categories in the CRC. ${ }^{7}$ In relation to this right, it can be seen for example in Article 6 of the CRC, which states: "1. States Parties recognize that every child has the inherent right to life. 2. States Parties shall ensure to the maximum extent possible the survival and development of the child. "This shows that the state must guarantee the survival of these children. On this basis, the judge in deciding who will care for the child after the divorce should also pay attention to the ability of the party who will care for

\footnotetext{
${ }^{6}$ Rosalinda. (2020). "Prinsip Kepentingan Terbaik Bagi Anak Dalam Perlindungan Hukum Anak Luar Kawin”. Disertasi, Program DoktorllmuHukum,FakultasHukumUniversitasAirlangga, Surabaya: 23.

${ }^{7}$ Purwanto. (2020). "Perlindungan Hukum Terhadap Anak Sebagai Korban Tindak Pidana Dalam Perspektif Hukum Positif Indonesia”. Jurnal Ilmu Hukum, 6(1): 77-93.
} 
the child. ${ }^{8}$ The ability in question is of course not only financially, but also emotionally, psychologically, and in other aspects.

2. The Child's Consent/Wish

Concerning the child's wish, the judge should have presented the child as a witness to understand the child's preferences regarding whom the child will be cared for. In Article 10 of Law 35/2014, the child can provide testimony, where it states that: "Every child has the right to state their opinion, receive, seek, and provide information according to the level of intelligence and age for the sake of self-development following the values of decency and propriety" This is important to do to ensure the consent/wish of the child, because when the judge decides that the child is to be cared for by the father, but it turns out that the child feels uncomfortable and feels more comfortable being cared for by the mother it will be horrible for the experience and state of the child. This is regulated in Article 9 paragraph (1) of the CRC, namely: "States Parties shall ensure that a child shall not be separated from his or her parents against their will (emphasis of the sentence given by the author) ..." Not to mention that it would be very unfair when a child is not asked about the preferences and is suddenly "forced" to be cared for by someone they do not want. It should be noted, however, that this child was in this situation, not because of the child's fault. Theoretically, Ronald Dworkin classified option luck and brute luck. Option luck is a condition that occurs as a result of our choices or decisions, while brute luck is a condition that occurs not as a result of our choices or decisions. ${ }^{9}$ Thus, it is very natural that the wishes of the child are to be understood, considering that there is care only by one of the parents, not a result of the child's choice. Thus, when the judge will decide who the child will be cared for, the judge is obliged to ask the child. Of course, the judge, in his wisdom, must provide questions properly and comfortably so that the child does not become depressed.

To apply these 2 (two) aspects in determining child custody, then concerning the classification of Muslim and non-Moslem couples as discussed above, it leads to:

1. Moslem couples

As explained above, regarding the determination of child custody for Muslim couples, there are differences, namely for children aged 12 (twelve) and over and children under 12 (twelve) years old.

a) For Children Age 12 (twelve) Years and Above For children aged 12 (twelve) years and over, the judge should pay attention to 2 (two) aspects, namely the cumulative needs and desires of the child. This is done so that the determination of child custody reflects the principle of the best interest of the child holistically.Thus, judges should not immediately prioritize giving custody to mothers, but must pay attention to aspects of the needs and desires of the child. In connection with this matter,the judge has also begun to apply it in several decisions. One of the decisions using this consideration can be seen in the CilegonReligious Court Decision Number 443 / Pdt.G / 2018 / PA.Clg. In his ratio decedendi the judge stated that:

Considering, that the four children of the Plaintiff and the Defendant were mumayyiz or 12 years old and over and their statements and opinions regarding the right to

\footnotetext{
${ }^{8}$ M. NatsirAsnawi. (2019). "Penerapan Model Pengasuhan Bersama (Shared Parenting) Dalam Penyelesaian Sengketa Hak Asuh Anak". Al-Iqtishadiyah, 5(1): 61-76.

${ }^{9}$ Joar Björk, Gert Helgesson, Niklas Juth. (2020). "Better in Theory Than in Practise? Challenges When Applying the Luck Egalitarian Ethos in Health Care Policy". Medicine, Health Care and Philosophy: p.2.
} 
care for themselves had been heard. on the questions by the Panel of Judges, the first, third, and fourth children chose for their mother as for the right to care for themselves, while the second child chose for the father / Defendant for the right to care for himself.

Based on these considerations, it can be seen that the judge determines the custody of the first, third, and fourth children to the mother, while for the second child, custody is given to the father. In this case, besides the judge considering the abilities of their father and mother, the judge also considered the wishes of the children to be cared by whom. This shows that judges have begun to consider the use of the principle of the best interest of the child in determining child custody.

b) For Children Below 12 (twelve) years Old

In Article 105 letter a in CIL/ KHI, it can be seen that the custody is given absolutely to the mother. However, judges should also pay attention to the provisions regarding the principle of the best interest of the child which are regulated in the CRC which in fact has been ratified by Presidential Decree 36/1990. Thus, the judge should also consider the wishes and needs of the child and not necessarily give custody of the mother, even though the child is under 12 (twelve) years old.

\section{Non-Moslem Couples}

For non-Muslim couples, there is no provision which inexperisverbis manner regulates who is given custody of children. Only based on jurisprudence, which is usually given to the mother of the child. Regarding the use of the principle of the best interest of the child in determining the provision of custody, the judge does not necessarily give priority to the mother but should consider the wishes and needs of the child. Judges have also begun to acknowledge this matter. This can be seen in the issuance of Supreme Court Letter Number 1 of 2017 which incidentally is a guideline for judges in Indonesia that should be obeyed. ${ }^{10}$ In the Formulation of the Civil Chamber, the Supreme Court Letter Number 1 of 2017 , states that:

"The right of a biological mother to care for a minor after the divorce can be given to the biological father as long as the granting of this right has a positive impact on the child's growth and development by taking into account the interests / existence / desires of the child during the divorce process."

Thus, when the child wants and the father of the child has the ability to care for the child, it is possible that the father is given custody of the child.

\section{CONCLUSION}

There are differences for judges in determining child custody in Indonesia between Muslim and non-Muslim couples. For Muslim couples, if the child is over 12 (twelve) years old, the custody of the child is prioritized to the mother and if the child is 12 (twelve) years of age and over, then custody will definitely be given to the mother. For non-Muslim couples generally the custody of the child will be given priority to the mother.

\footnotetext{
${ }^{10}$ Irwan Adi Cahyadi. (2014). "Kedudukan Surat Edaran Mahkamah Agung (SEMA) Dalam Hukum Positif Di Indone sia”. Jurnal Hukum, 2(1): 1-19.
} 
The basis for determining the provision of child custody that reflects the principle of the best interest of the child for Muslim couples is that if the child is over 12 (twelve) years of age, the judge should not necessarily prioritize giving custody to the mother, but should consider the aspects of the needs and the wishes of the child. If the child is under 12 (twelve) years old, the judge should also consider the wishes and needs of the child and not necessarily give custody to the mother. The basis for determining the provision of child custody that reflects the principle of the best interest of the child for non-Muslim couples is when the judge does not necessarily give priority to the mother, but should consider the wishes and needs of the child.

\section{Bibliography}

Books with an author:

John Henry Merryman. (1985). The Civil Law Tradition: An Introduction to The Legal System of Western Europe And Latin America. 2nd Ed., California: Stanford University Press. Journal articles:

Irwansyah. (2013). "Jejak Demokrasi Lingkungan dalam Undang-Undang Nomor 32 Tahun 2009” Jurnal IlmuHukumAmannaGappa, 21(2): 121-131.

Muhammad Helmi. (2016). "Kedudukan Instruksi Presiden Nomor 1 Tahun 1991 Tentang Kompilasi Hukum Islam Menurut Peraturan Perundang-Undangan di Indonesia". Mazahib: JurnalHukum Islam, 15(1): 139-150

Zulfiani. (2017). "Kajian Hukum Terhadap Perkawinan Anak Di Bawah Umur Menurut Undang-Undang Nomor 1 Tahun 1974”. Jurnal Hukum: Samudra Keadilan, 12(2): $211-222$

RizaMasruroh. (2017). "Implementasi Prinsip Mempersukar Perceraian Dalam UndangUndang Nomor 1 Tahun 1974 Tentang Perkawinan Perspektif Maqâsid Al-Syari 'ah". Tesis, Magister Ilmu Agama Islam, UinWalisono Semarang: 26.

AchmadTubagusSurur, HanikRosyidah. (2016). "Perceraian Dini: Studi Terhadap Putusan Pengadilan Agama Pekalongan". Jurnal Hukum Islam, 14(1): 111-133

HayatulIsmi. (2016). "Recognition and Legal Protection of Indigenous Peoples' Rights to Indegenous Land in the Effort to Reform the HayatulIsmi National Law". Journal of Legal Studies, 3 (1): 1-22.

Choky R. Ramadhan. (2018). "Konvergensi Civil Law dan Common Law di Indonesia dalam Penemuan dan Pembentukan Hukum". Mimbar Hukum, 30(2): 214-226.

MardalenaHanifah. (2018). "Perkawinan Beda Agama DitinjaudariUndang-undangNomor 1 Tahun 1974Tentang Perkawinan". Soematra Law Review, 2(2): 297-308.

Peter Jeremiah Setiawan, Xavier Nugraha, Michael Enrick. (2020). “Analisis Kedudukan Keterangan Korban Terkait Kejahatan Terhadap Harta Kekayaan Dalam Lingkungan Keluarga: Sebuah AntinomiAntaraHukumMaterilDenganFormil”. Al-Daulah: Jurnal Hukum Pidana dan Ketatanegaraan, 9(1): 99-118.

EnjuJuanda. (2017). "Penalaran Hukum (Legal Reasoning)". GaluhJustisi, 5(1): 157-167.

Muhammad Yassin. (2016). "Perlindungan Hukum Bagi Warga Negara Dalam Pelaksanaan Mutasi Pegawai Negeri Sipil”. Yuridika, 31(2): 254-272. 
Purwanto. (2020). "Perlindungan Hukum Terhadap Anak Sebagai Korban Tindak Pidana Dalam Perspektif Hukum Positif Indonesia”. Jurnal Ilmu Hukum, 6(1): 77-93.

M. NatsirAsnawi. (2019). "Penerapan Model Pengasuhan Bersama (Shared Parenting) Dalam Penyelesaian Sengketa Hak Asuh Anak". Al-Iqtishadiyah, 5(1): 61-76.

JoarBjörk, Gert Helgesson, NiklasJuth. (2020). "Better in Theory Than in Practise? Challenges When Applying the Luck Egalitarian Ethos in Health Care Policy". Medicine, Health Care and Philosophy: 2.

Irwan Adi Cahyadi. (2014). "Kedudukan Surat Edaran Mahkamah Agung (SEMA) Dalam Hukum Positif Di Indonesia”. Jurnal Hukum, 2(1): 1-19.

Thesis/ Dissertation:

Rosalinda. (2020). "Prinsip Kepentingan Terbaik Bagi Anak Dalam Perlindungan Hukum Anak Luar Kawin”. Disertasi, Program Doktor Ilmu Hukum, Fakultas Hukum Universitas Airlangga, Surabaya. 